\title{
CAPUTO TYPE MODIFICATION OF THE ERDÉLYI-KOBER COUPLED IMPLICIT FRACTIONAL DIFFERENTIAL SYSTEMS WITH RETARDATION AND ANTICIPATION
}

\author{
Mokhtar Boumaaza, Mouffak Benchohra* and Juan J. Nieto
}

\begin{abstract}
In this paper, we deal with the existence and uniqueness of solutions of a coupled system of nonlinear implicit fractional differential equations of Caputo-type modification of the Erdélyi-Kober involving both retarded and advanced arguments. The arguments are based upon the Banach contraction principle and Schauder's fixed point theorem. An example is included to show the applicability of our outcomes.
\end{abstract}

Mathematics subject classification (2010): 34A08, 34K05.

Keywords and phrases: Coupled fractional differential system implicit of Caputo-type modification of the Erdélyi-Kober, existence, retarded arguments, advanced arguments, fixed point.

\section{REFERENCES}

[1] S. Abbas, M. Benchohra, J. R. Graef, J. Henderson, Implicit Fractional Differential and Integral Equations: Existence and Stability, de Gruyter, Berlin 2018.

[2] S. Abbas, M. Benchohra, G. M. N'Guérékata, Topics in Fractional Differential Equations, Springer, New York 2012.

[3] S. Abbas, M. Benchohra and G. M. N’Guérékata, Advanced Fractional Differential and Integral Equations, Nova Science Publishers, New York, 2015.

[4] S. AbBAs, M. Benchohra, J. LAZReg AND G. N'GuÉrÉKATA, Weak solutions for implicit Pettis Hadamard fractional differential equations with retarded and advanced arguments, Nonlinear Stud. 24 (2) (2017), 355-365.

[5] S. Abbas, S. Aibout, M. Benchohra, M. Bohner, A coupled Caputo-Hadamard fractional differential system with multipoint boundary conditions, Dyn. Cont., Disc. Impul. Syst. (to appear).

[6] S. Abbas, M. Benchohra, And A. N. Vityuk, On fractional order derivatives and Darboux problem for implicit differential equations, Fract. Calc. Appl. Anal. 15 (2), (2012), 168-182.

[7] S. Abbas, M. Benchohra, N. Hamidi And Y. Zhou, Implicit coupled Hilfer-Hadamard fractional differential systems under weak topologies, Adv. Difference Equ. 328 (2018), 17 pp.

[8] S. Aljoudi, B. Ahmad, J. J. Nieto, A. A Als Aedi, Coupled system of Hadamard type sequential fractional differential equations with coupled strip conditions, Chaos Solitons Fractals 91 (2016), 3946.

[9] R. P. Agarwal, S. K. Ntouyas, B. Ahmad, And A. K. Alzahrani, Hadamard-type fractional functional differential equations and inclusions with retarded and advanced arguments, Adv. Difference Equ. 2016, 2016:92, 15 pp.

[10] B. AL-SAQABI, V. S. KIRYAKOVA, Explicit solutions of fractional integral and differential equations involving Erdélyi-Kober operators, Appl. Math. Comput. 95 (1998), no. 1, 1-13.

[11] T. D. BEnAVIDES, An existence theorem for implicit differential equations in a Banach space, Ann. Mat. Pura Appl. (4) 118 (1978), 119-130.

[12] M. Benchohra, S. Bouriah, J. E. Lazreg and J. J. Nieto, Nonlinear implicit Hadamard fractional differential equations with delay in Banach space, Acta Univ. Palack. Olomuc. Fac. Rerum Natur. Math. 55 (2016), 15-26. 
[13] M. Benchohra, S. Bouriah and J. Henderson, Nonlinear implicit Hadamard's fractional differential equations with retarded and advanced arguments, Azerbaijan J. Math. 8 (2) (2018), 72-85.

[14] M. Benchohra AND J. E. LAZREG, Nonlinear fractional implicit differential equations, Commun. Appl. Anal. 17 (2013), 471-482.

[15] M. Benchohra, J. E. LAZReg ANd G. N'GuéréKATA, Nonlinear implicit Hadamard's fractional differential equations on Banach space with retarded and advanced arguments, Intern. J. Evol. Equ. 10 (3 \& 4) (2017), 283-295.

[16] F. Z. Berrabah, B. Hedia, J. Henderson, A fully Hadamard and Erdélyi-Kober-type integral boundary value problem of a coupled system of implicit differential equations, Turkish J. Math. $\mathbf{4 3}$ (2019), no. 3, 1308-1329.

[17] A. Granas and J. Dugundji, Fixed Point Theory, Springer-Verlag, New York, 2003.

[18] T. Gnana Bhaskar, V. Lakshmikantham and J. Vasundhara Devi, Monotone iterative technique for functional differential equations with retardation and anticipation, Nonlinear Anal. 66 (2007), no. 10, 2237-2242.

[19] R. HILFER, Applications of Fractional Calculus in Physics, World Scientific, Singapore 2000.

[20] A. A. Kilbas, Hari M. SRivastava, And Juan J. Trujillo, Theory and Applications of Fractional Differential Equations, North-Holland Mathematics Studies, 204. Elsevier Science B. V., Amsterdam, 2006.

[21] V. Kiryakova, Generalized Fractional Calculus and Applications, Pitman Research Notes in Math. 301, Longman, Harlow J. Wiley, New York, 1994.

[22] V. Kiryakova, Y. LUCHKO, Multiple Erdélyi-Kober integrals and derivatives as operators of generalized fractional calculus. Handbook of fractional calculus with applications, Vol. 1, 127-158, De Gruyter, Berlin, 2019.

[23] Y. LuchKo And J. J. Trujillo, Caputo-type modification of the Erdélyi-Kober fractional derivative, Fract. Calc. Appl. Anal. 10 (3) (2007), 249-267.

[24] I. Podlubny, Fractional Differential Equations, Academic Press, San Diego, 1999.

[25] V. E. Tarasov, Fractional Dynamics Application of Fractional Calculus to Dynamics of Particles, Fields and Media, Springer, Heidelberg; Higher Education Press, Beijing, 2010.

[26] A. S. VATSALA, Generalized monotone iterative technique for functional differential equations with retardation and anticipation, Nonlinear Dyn. Syst. Theory 7 (2007), no. 4, 431-438.

[27] A. N. Vityuk AND A. V. Mikhalenko, The Darboux problem for an implicit differential equation of fractional order, Ukr. Mat. Visn. 7(4) (2010), 439-452.

[28] Y. Zhou, J.-R. WAng, L. Zhang, Basic Theory of Fractional Differential Equations, second edition, World Scientific Publishing Co. Pte. Ltd., Hackensack, NJ, 2017. 